Research.

\title{
The effect of quality of worklife and job satisfaction on organizational commitment
}

\author{
Sri Marti Pramudena ${ }^{1^{*}}$, Asmy Fuzita Hilda ${ }^{2}$ \\ ${ }^{1 *}$ Department of Management, Economic College of Binaniaga, Bogor, Indonesia \\ ${ }^{2}$ Department of Management, Economic College of Binaniaga, Bogor, Indonesia \\ dena_pramu@yahoo.com (S. M. Pramudena), asmyfuzita@gmail.com (A. F. Hilda) \\ * Corresponding author
}

Received: April 29, 2019; Accepted: May 25, 2019; Published: June 30, 2019

To cite this article: Pramudena, Sri Marti, Asmy Fuzita Hilda. 2019. The effect of quality of worklife and job satisfaction on organizational commitment. The Management Journal of BINANIAGA. 4 (1): 23-36. doi:

\begin{abstract}
This study aims to determine the effect of work life quality and job satisfaction on organizational commitment. Collection research data through interviews, observation, and distribution of questionnaires to 110 respondent. The sample in this study were employees who worked at PT. Intrasari Raya Bogor. The sampling method uses simple random sampling. The research data was analyzed using the SPSS version 20. The results showed that work life quality and job satisfaction on organizational commitment had a positive and significant effect, both partially and simultaneously where t-value 4.694>t-table 1.6592 and F-value 31.054>F-table 3.08. Organizational commitment of $64.5 \%$ is influenced by other variables not included in this study. Companies are expected to be able to think of other strategies in implementing quality work life and increasing employee satisfaction so as to create strong employee commitment.
\end{abstract}

Keywords: Quality of Work Life, Job Satisfaction, Organizational Commitment

\section{Background}

Today's business is very dynamic, demanding companies to always be creative in finding ways to deal with competition. Optimization of the function of human resources is a strategy to achieve excellence, however, to retain employees it is necessary to implement quality work life that aims to improve employee satisfaction. The application of quality work life must be able to provide work motivation to employees, so as to strengthen employee organizational commitment.

Improving the quality of work life will have a positive impact on an employee to behave both inside and outside the work environment. In Indonesia, the quality of work life in a standard manner can be fulfilled by the implementation of the Manpower Act No. 13 of 2003 which includes regulating equal opportunity and treatment, job training, employment relations, protection, remuneration, employee welfare, and industrial relations.

The application of good quality work life is the company's concern in shaping employee job satisfaction. Satisfaction is an individual thing, where each individual has different satisfaction. Employees who have high satisfaction, generally will have a high commitment to the company. High commitment will contribute to the company to increase

Sri Marti Pramudena and Asmy Fuzita Hilda. The effect of quality of worklife and job satisfaction on organizational commitment 
the productivity of both employees and companies. Employees will work well as they do treated by the company.

If employees get the results of the company as expected, there will be employee commitment. This is a direct relationship between human resource management and the level of employee commitment to the company. Good treatment for employees can motivate them to achieve goals in all fields. They will contribute voluntarily and will do things that are more than expected by the company. The purpose of the company with commitment is so that employees can achieve the desired expectations of the company optimally, both in the short and long term.

\section{Literature Review}

\section{Quality of Work Life}

According to Faghih et.al. (2013) in Priambodo (2016) defines that the quality of work life is the perception of employees regarding welfare, atmosphere, and work experience that refers to how effective the work environment is. According to Cascio (2001) in Irawati (2015) which explains that the quality of work life is an opportunity given to employees in determining decisions about their employees and the design of the workplace. According to Safrizal (2014) in Jati (2013) the quality of work life is a level where members of an organization are able to satisfy important personal needs through their experience in doing work for the organization.

Based on these theories, it can be synthesized that the quality of work life is a set of employee perceptions of security and comfort in work and conditions for growing and developing as human beings whose aim is to be able to improve welfare, fulfill expectations, and work life that is more meaningful and beneficial for himself. The indicators in measuring the quality of work life developed by Cascio are:

\section{a. Innovative rewards}

The rewards given to employees are expected to be obtained satisfying various needs in accordance with the standard of living of the employees concerned with the existing wage and payroll standards that apply accordingly. This reward system includes salaries, benefits, bonuses, and various other facilities which are considered as rewards for the work of the employees at work.

b. Work environment

A conducive work environment is very much the influence of employees at work. This includes relating to the determination of working hours, applicable regulations, leadership attitudes, and physical environment. This work environment is important, especially for the health, safety and security of employees in carrying out their duties.

c. Work restructuring

Provide opportunities for employees to get challenging work (job enrichment) and wider opportunities for employee self-development. This can encourage employees to further develop themselves.

\section{Job Satisfaction}

According to Sutrisno (2010) means that job satisfaction is an important problem that is considered in relation to employee work productivity and dissatisfaction often associated with high levels of demands and work complaints. Workers with high levels of dissatisfaction are more likely to commit passive sabotage and aggression. According to Sunyoto (2012) job satisfaction (job satisfaction) is a pleasant or unpleasant emotional state where employees view their

Sri Marti Pramudena and Asmy Fuzita Hilda. The effect of quality of worklife and job satisfaction on organizational commitment 
work. Job satisfaction reflects a person's feelings for his job. Robbins (2015) states that job satisfaction is a positive sense of satisfaction about the work of the employee as a result of evaluating the work characteristics. Job satisfaction according to Hasibuan (2008) is an emotional state that is pleasant and loves his work, whereas according to Wether \& Davis in Afifuddin (2017) that job satisfaction is an emotional state that pleases employees to view their work. Job satisfaction reflects a person's feelings for his job.

Based on these theories, it can be synthesized that satisfaction work is the assessment of employees about how far their overall work can satisfy their needs. Job satisfaction is also a general attitude which is the result of several special attitudes towards work factors, adjustment and individual social relationships outside of work. The indicators of job satisfaction are as follows:

a. Enjoy his job

The person who is aware of the direction in which he leads, why is he take that path, and how he must go to his goal. He likes his job because he can do it well.

b. Loving his work

Giving something the best devotes all forms of attention with all the heart that is possessed with all the effort to aim for the best results for his work. Employees want to sacrifice themselves even though it is difficult, even though they are sick, with no time, wherever employees are always thinking about their work.

c. Work morale

An inner agreement that arises from within a person or group of people to achieve a certain goal in accordance with the set quality standards.

d. Discipline

Conditions that are created and formed through the process of a series of behaviors that show the values of obedience, obedience, loyalty, order and/or order.

e. Work performance

The results of work achieved by someone in carrying out the tasks assigned to him are based on skill and sincerity as well as time.

\section{Organizational Commitment}

According to Triatna (2016), defining organizational commitment is a level of loyalty of members/employees/employees to the organization/company that is characterized by its desire to remain part of the organization, do the best for the organization, and always maintain the good name of the organization. According to Sutrisno (2015) states that organizational commitment is the attitude of employee loyalty to the organization and is also a process of expressing attention and participation in the organization. According to Kaswan (2018) states that organizational commitment is a work attitude within a form of desire, willingness, dedication, loyalty, and / or strong trust that shows desire to remain part of the organization's members by accepting the values and goals of the organization, and working on behalf of/for the benefit of the organization. According to Robbins (2016) suggests that organizational commitment is the level where an employee identifies himself with a particular organization and its objectives.

Based on these theories, it can be synthesized that organizational commitment is all forms of loyalty attitudes held by employees to the organization or

Sri Marti Pramudena and Asmy Fuzita Hilda. The effect of quality of worklife and job satisfaction on organizational commitment 
will not leave the organization and always take sides for the interests of the organization and earnestly achieve organizational goals. The indicators are:

\section{a. Affective Commitment}

Shows the strong emotional desires of employees for adapt to existing values so that the goals and desires to remain organized can be realized. Affective commitment can arise in an employee due to individual characteristics, organizational structure characteristics, task significance, various skills, feedback from leaders, and involvement in management.

b. Continuance Commitment

Commitments that are based on one's concerns about losing something that has been obtained during the organization, such as salary, facilities, and others. Matters that cause a continuation commitment, including age, position, and various facilities and benefits obtained.

\section{c. Normative Commitment}

Demonstrate the moral responsibility of employees to stay in the organization. The cause of this commitment, namely social demands that are the result of one's experience in interacting with others or the emergence of permanent compliance with a role model or organization owner due to remuneration, social respect, culture, or religion.

4. Framework

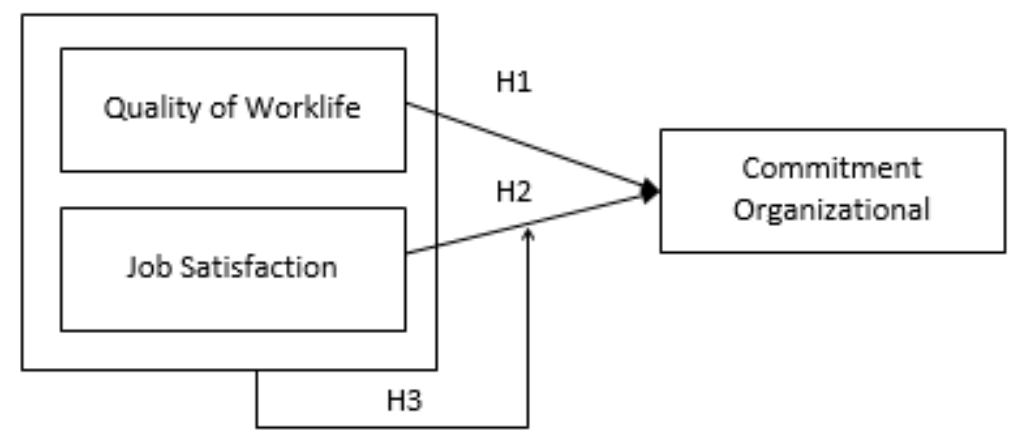

Figure 1.

Research Framework

5. Research Hypothesis

a. The first hypothesis is thought to have an influence between the qualities of work life on organizational commitment.

b. The second hypothesis is thought to have an influence between job satisfactions on organizational commitment.

c. The third hypothesis is thought to have an influence between quality work life and satisfaction work towards organizational commitment.

\section{Research Methodology}

1. Variables and Measurements

The research method used is associative research which aims to determine the influence or relationship between two or more variables.

Sri Marti Pramudena and Asmy Fuzita Hilda. The effect of quality of worklife and job satisfaction on organizational commitment 
a. Independent Variables

The independent variable is a variable that affects or is the cause of the change or the emergence of the dependent variable. In this study, the independent variables are work life quality and job satisfaction.

b. Dependent Variables

Dependent variable is a variable that is influenced or that becomes a result, because of the existence of independent variables. In this study, the dependent variable is organizational commitment.

c. Measurement Scale

Distribution of questionnaires was conducted to measure the perceptions of respondents used Likert scale (Likert Summated Ratings). The research instrument uses a Likert scale in the form of a checklist. Based on the scale of measurement, this study uses five categories of answers that contain variations in stratified values, including:

Table 1

Likert Scale

\begin{tabular}{|l|c|}
\hline \multicolumn{1}{|c|}{ Answer } & Score \\
\hline Strongly Agree & 5 \\
\hline Agree & 4 \\
\hline Neutral & 3 \\
\hline Disagree & 2 \\
\hline Strongly Disagree & 1 \\
\hline
\end{tabular}

2. Population and Samples

According to Sugiyono (2016: 80), population is a region of generalization (generalization) consisting of objects/subjects that have certain qualities and characteristics set by researchers to be studied and then conclusions drawn. The population in this study were 153 employees working at PT. Intrasari Raya Bogor.

The sample is part of the number and characteristics of the population. Determination of the number of samples using Slovin formula and got the results that the sample used in this study were 110 respondents. The sampling technique using simple random sampling.

3. Data Collection Method

a. Questionnaire is a method of data collection done by giving questions to respondents. Questionnaire in this study some were distributed directly to respondents and also used the google form which was sent via e-mail or whatsapp to each respondent.

b. The interview is a method of collecting data by road question and answer is done based on the goal research, and by analyzing behavior by observing individuals or groups directly.

Sri Marti Pramudena and Asmy Fuzita Hilda. The effect of quality of worklife and job satisfaction on organizational commitment 
The Management Journal of BINANIAGA Vol. 04, No. 01, June 2019

p-ISSN: 2527 - 4317, e-ISSN: $2580-149 x$

$6^{\text {th }}$ Accreditation Rating: April 04, 2019-April 03, 2024

\section{Results and Discussion}

1. Research Results

Table 2

Validity Test Results

\begin{tabular}{|c|c|c|c|c|c|}
\hline Varibles & Indicators & Codes & r-values & r-tables & Results \\
\hline \multirow{8}{*}{ QW } & \multirow{2}{*}{$\begin{array}{l}\text { Innovative } \\
\text { Rewards }\end{array}$} & X1.1 & 0,376 & 0,361 & VALID \\
\hline & & $\mathrm{X} 1.2$ & 0,448 & 0,361 & VALID \\
\hline & \multirow{3}{*}{$\begin{array}{c}\text { Work } \\
\text { Environment }\end{array}$} & $\mathrm{X} 1.3$ & 0,612 & 0,361 & VALID \\
\hline & & $\mathrm{X} 1.4$ & 0,267 & 0,361 & INVALID \\
\hline & & $\mathrm{X} 1.5$ & 0,528 & 0,361 & VALID \\
\hline & \multirow{3}{*}{$\begin{array}{c}\text { Work } \\
\text { Restructuring }\end{array}$} & $\mathrm{X} 1.6$ & 0,770 & 0,361 & VALID \\
\hline & & $\mathrm{X} 1.7$ & 0,608 & 0,361 & VALID \\
\hline & & $\mathrm{X} 1.8$ & 0,570 & 0,361 & VALID \\
\hline \multirow{11}{*}{ JS } & \multirow{3}{*}{ Enjoy to Work } & $\mathrm{X} 2.1$ & 0,363 & 0,361 & VALID \\
\hline & & $\mathrm{X} 2.2$ & 0,614 & 0,361 & VALID \\
\hline & & $\mathrm{X} 2.3$ & 0,498 & 0,361 & VALID \\
\hline & \multirow[t]{2}{*}{ Loving to Work } & $\mathrm{X} 2.4$ & 0,388 & 0,361 & VALID \\
\hline & & $\mathrm{X} 2.5$ & 0,341 & 0,361 & INVALID \\
\hline & \multirow[t]{2}{*}{ Work Moral } & $\mathrm{X} 2.6$ & 0,621 & 0,361 & VALID \\
\hline & & $\mathrm{X} 2.7$ & 0,221 & 0,361 & INVALID \\
\hline & \multirow[t]{2}{*}{ Work Dicipline } & $\mathrm{X} 2.8$ & 0,382 & 0,361 & VALID \\
\hline & & $\mathrm{X} 2.9$ & 0,402 & 0,361 & VALID \\
\hline & \multirow{2}{*}{$\begin{array}{c}\text { Work } \\
\text { Performance }\end{array}$} & $\mathrm{X} 2.10$ & 0,700 & 0,361 & VALID \\
\hline & & $X 2.11$ & 0,490 & 0,361 & VALID \\
\hline \multirow{10}{*}{$\mathrm{CO}$} & \multirow{3}{*}{$\begin{array}{c}\text { Affective } \\
\text { Commitment }\end{array}$} & Y.1 & 0,739 & 0,361 & VALID \\
\hline & & Y.2 & 0,557 & 0,361 & VALID \\
\hline & & Y.3 & 0,681 & 0,361 & VALID \\
\hline & \multirow{4}{*}{$\begin{array}{l}\text { Normative } \\
\text { Commitment }\end{array}$} & Y.4 & 0,371 & 0,361 & VALID \\
\hline & & Y.5 & 0,409 & 0,361 & VALID \\
\hline & & Y.6 & 0,255 & 0,361 & INVALID \\
\hline & & Y.7 & 0,180 & 0,361 & INVALID \\
\hline & \multirow{3}{*}{$\begin{array}{l}\text { Continued } \\
\text { Commitment }\end{array}$} & Y.8 & 0,667 & 0,361 & VALID \\
\hline & & $Y .9$ & 0,617 & 0,361 & VALID \\
\hline & & $Y .10$ & 0,685 & 0,361 & VALID \\
\hline
\end{tabular}

*) $\mathrm{QW}=$ Quality of Work, JS=Job Satisfaction, CO=Commitment Organization

Based on the results of the validity test, there are 5 items that are invalid statements because of the t-value $<$-table. The researcher does not use these invalid statements.

Table 3

Reliability Test Results

\begin{tabular}{|l|c|c|c|}
\hline \multicolumn{1}{|c|}{ Variables } & $\begin{array}{c}\text { Cronbach } \\
\text { Alpha }\end{array}$ & $\begin{array}{c}\text { Cut of } \\
\text { Value }\end{array}$ & Results \\
\hline Quality of Work & 0,718 & 0,600 & Reliable \\
\hline Job Satisfaction & 0,709 & 0,600 & Reliable \\
\hline
\end{tabular}

Sri Marti Pramudena and Asmy Fuzita Hilda. The effect of quality of worklife and job satisfaction on organizational commitment 


\begin{tabular}{|l|c|c|c|}
\hline \multicolumn{1}{|c|}{ Variables } & $\begin{array}{c}\text { Cronbach } \\
\text { Alpha }\end{array}$ & $\begin{array}{c}\text { Cut of } \\
\text { Value }\end{array}$ & Results \\
\hline $\begin{array}{l}\text { Commitment } \\
\text { Organization }\end{array}$ & 0,770 & 0,600 & Reliable \\
\hline
\end{tabular}

Based on the results of the reliability test, the variable quality of work life, job satisfaction, and organizational commitment is reliable because the value of Cronbach Alpha > 0.600 (Sugiyono, 2016).

Table 4

Classification of Respondents

\begin{tabular}{|c|c|c|}
\hline Characteristics & Total & $\%$ \\
\hline \multicolumn{3}{|l|}{ Gender } \\
\hline Male & 57 & $52 \%$ \\
\hline Female & 53 & $48 \%$ \\
\hline \multicolumn{3}{|l|}{ Age } \\
\hline$<25$ Year & 15 & $14 \%$ \\
\hline 25 - 30 Year & 46 & $42 \%$ \\
\hline 31 - 40 Year & 33 & $30 \%$ \\
\hline$>40$ Year & 16 & $15 \%$ \\
\hline \multicolumn{3}{|l|}{ Education } \\
\hline Senior High School & 52 & $47 \%$ \\
\hline Diploma & 14 & $13 \%$ \\
\hline Bachelor & 44 & $40 \%$ \\
\hline \multicolumn{3}{|l|}{ Working Period } \\
\hline$<1$ Year & 7 & $6 \%$ \\
\hline 1 - 5 Year & 41 & $37 \%$ \\
\hline $6-10$ Year & 38 & $35 \%$ \\
\hline > 10 Year & 24 & $22 \%$ \\
\hline
\end{tabular}

Table 5

Initial Indication Analysis

\begin{tabular}{|c|c|c|}
\hline Statement & Agree (4-5) & Disagree (1-3) \\
\hline QW & & \\
\hline$X 1.1$ & 69,1 & 30,9 \\
\hline$X 1.2$ & 67,2 & 32,8 \\
\hline$X 1.3$ & 82,8 & 17,2 \\
\hline$X 1.5$ & 85,4 & 14,6 \\
\hline$X 1.6$ & 49,1 & 50,9 \\
\hline
\end{tabular}

Sri Marti Pramudena and Asmy Fuzita Hilda. The effect of quality of worklife and job satisfaction on organizational commitment 


\begin{tabular}{|c|c|c|}
\hline Statement & Agree (4-5) & Disagree (1-3) \\
\hline X1.7 & 68,2 & 31,8 \\
\hline X1.8 & 48,2 & 51,8 \\
\hline JS & & \\
\hline X2.1 & 93,6 & 6,4 \\
\hline X2.2 & 99,1 & 0,9 \\
\hline X2.3 & 92,7 & 7,3 \\
\hline X2.4 & 54,5 & 45,5 \\
\hline X2.5 & 95,5 & 4,5 \\
\hline X2.6 & 80 & 20 \\
\hline X2.7 & 94,5 & 5,5 \\
\hline X2.8 & 53,6 & 46,4 \\
\hline CO & 90 & 10 \\
\hline Y.1 & & \\
\hline$Y .2$ & 95,4 & 4,6 \\
\hline$Y .3$ & 83,6 & 16,4 \\
\hline$Y .4$ & 96,4 & 3,6 \\
\hline$Y .5$ & 88,2 & 11,8 \\
\hline$Y .8$ & 91,8 & 8,2 \\
\hline Y.10 & 44,5 & 55,5 \\
\hline & 42,7 & 57,3 \\
\hline
\end{tabular}

Table 6

Classic assumption test

\begin{tabular}{|l|r|r|r|c|}
\hline \multicolumn{1}{|c|}{ Model } & $\begin{array}{c}\text { Asymp Sig. } \\
\text { (2- tailed) }\end{array}$ & Tolerance & VIF & Sig. \\
\hline Quality of Work & 0,737 & 0,953 & 1,050 & 0,365 \\
\hline Job Satisfaction & 0,737 & 0.953 & 1,050 & 0,082 \\
\hline
\end{tabular}

Based on the results of the normality test in the table it is known that the significance value is $0.737>0.05$, then the residual value is normally distributed. These results indicate that the tolerance value is greater than 0.10 and the VIF value is smaller than 10.00 , so this study does not show any symptoms of multicollinearity. This result shows these variables the significance value is $>0.05$. That is, there are no symptoms of heteroscedasticity or this study is free of heteroscedasticity.

For the level of closeness of the relationship obtained by the results of multiple correlation analysis with a value of 0.606 . Based on the interpretation of the correlation coefficient from Sugiyono (2013), the degree of relationship between work life quality and job satisfaction on organizational commitment has a strong correlation.

The results of multiple regression analysis get the equation:

The constant value of 5.892 indicates that the quality of work life and job satisfaction is value 0 , the organizational commitment value amounting to 5,892 .

The regression coefficient value of other independent variables is fixed and the quality of work life has increased by 1 , then the organizational commitment will increase by 0.335 . Positive sign in the equation shows a unidirectional relationship between the quality of work life and organizational commitment.

Regression coefficient values of other independent variables are fixed value and job satisfaction has increased 1, then organizational commitment will increase

Sri Marti Pramudena and Asmy Fuzita Hilda. The effect of quality of worklife and job satisfaction on organizational commitment 
by 0.471 . The positive sign in the equation shows a unidirectional relationship between job satisfaction and organizational commitment.

Table 7

t-test

\begin{tabular}{|l|c|c|c|c|c|}
\hline \multicolumn{1}{|c|}{ Model } & $\begin{array}{c}\text { Unstandardized } \\
\text { Coefficients }\end{array}$ & $\begin{array}{c}\text { Standardized } \\
\text { Coefficients }\end{array}$ & $t$ & Sig. & Model \\
\hline (Constant) & 5,892 & 3,399 & & 1,734 &, 086 \\
\hline Quality of Worklife &, 335 &, 071 &, 370 & 4,694 &, 000 \\
\hline Job Satisfaction &, 471 &, 091 &, 406 & 5,155 &, 000 \\
\hline
\end{tabular}

a. Dependent Variable: Commitment Organizational

Obtained $4.694>1.659$ thus due to the value of $t$-value $>t$-table then the first hypothesis can be accepted. This shows that partially the quality of work life has an influence on organizational commitment.

Obtained $5.155>1.659$ thus because the value of $t$-value $>t$-table of the second hypothesis can be accepted. This shows that partially job satisfaction has an influence on organizational commitment.

Table 8

F-Test

\begin{tabular}{|l|c|c|c|c|c|}
\hline \multicolumn{1}{|c|}{ Model } & $\begin{array}{c}\text { Sum of } \\
\text { Square s }\end{array}$ & df & $\begin{array}{c}\text { Mean } \\
\text { Square }\end{array}$ & F & Sig. \\
\hline Regression 1 & 354,850 & 2 & 177,425 & 31,054 &, $000^{\mathrm{b}}$ \\
Residual & 611,341 & 107 & 5,713 & & \\
Total & 966,191 & 109 & & & \\
\hline
\end{tabular}

a. Dependent Variable: Organizational Commitment

b. Predictors: (Constant), Job Satisfaction, Quality Worklife

These results indicate F-value 31,054 > F-table 3.08 which means that the third hypothesis can be accepted ie together (simultaneous) quality of work life and job satisfaction affect organizational commitment.

Based on the table, results Adjusted $R$ Square is equal to 0.355. Variable contribution to work life quality and job satisfaction towards organizational commitment is $35.5 \%$. The rest is equal to $64.5 \%$ organizational commitment is influenced by other variables not included in this study, such as variables such as work conflict, organizational culture, work motivation, and so on.

2. Discussion

a. Effect of Quality of Work Life on Organizational Commitment

The results of this study indicate that the quality of work life have a positive influence and significant to commitment organization. The better and improved quality of work life in the company, the more commitment will be

Sri Marti Pramudena and Asmy Fuzita Hilda. The effect of quality of worklife and job satisfaction on organizational commitment 
created to the employees who work in the company. This result is in line with research from Imanni (2014), Hayati (2016) and Priambodo (2016) that the quality of work life is influential towards organizational commitment, where the quality of work life good ones can improve employee commitment in a company. So, the first hypothesis in this study is accepted.

b. Effect of Job Satisfaction on Organizational Commitment

Against Organizational Commitment The results of this study indicate that job satisfaction has positive and significant influence towards organizational commitment. This means that employee job satisfaction at PT. Intrasari Raya Bogor, it will increasingly create strong organizational commitment in these employees.

This result is in line with research from Oktavianti (2014) and Sijabat (2011) that there is influence directly and positively related to job satisfaction on organizational commitment. These results explain that job satisfaction perceived by employees has a significant influence to encourage them to commit to the company. So, the more employees feel satisfied, the more employees have organizational commitment. So, the second hypothesis in this study was accepted.

\section{Effect of Quality of Work Life and Job Satisfaction on Organizational Commitment}

The results of the study using the $F$ test show that together the quality of work life and Job satisfaction influences organizational commitment. The results of this study indicate that employees of PT. Intrasari Raya Bogor has a commitment that is not strong enough. When employees have tried to provide participation through work performance, unfortunately, on the other hand the indicated company has not been able to appreciate this achievement. This is evidenced in the frequency distribution data which shows there are still some employees who plan to move to other companies. This result is thought to arise because of a discrepancy with the expectations of employees so that there is a feeling of dissatisfaction within themselves, such as work restructuring and work performance that has not been felt by employees.

These results are in line with research from Danik (2015) that work life quality and job satisfaction have an influence on commitment. The strongest commitment formed by employees of PT. Intrasari Raya Bogor is a continuance commitment. This is evidenced in the frequency distribution of employees who survive in this company so that they can fulfill their daily needs. This continued commitment often arises on the basis of consideration of profit and loss if it remains in the company or leaves the company. Planning for employee resignation is based on the presumption of employees that there are companies out there that might be better than PT. Intrasari Raya Bogor (55.5\%). Where it is evident that some employees intend to move to another company (57.3\%). So, if this keeps happening, the process of achieving company goals is hampered.

Based on the $F$ test, this study found that the quality of work life and job satisfaction proved to have a positive effect simultaneously (simultaneous) on organizational commitment with a significance value of $0,000<0,05$ and the results of multiple correlation analysis obtained a degree of closeness 0.606 (strong correlation). This means that if the quality of work life is implemented properly and employee job satisfaction is fulfilled, strong organizational commitment will be realized.

Robbins (2015) states that job satisfaction is a positive sense of satisfaction about the work of the employee as a result of evaluating the work characteristics. Of course, this will have the effect of increasing profits for the company. The results of multiple linear regression analysis state that that is very influential on the

Sri Marti Pramudena and Asmy Fuzita Hilda. The effect of quality of worklife and job satisfaction on organizational commitment 
organizational commitment of employees of PT. Intrasari Raya Bogor is job satisfaction because of the results of the value of job satisfaction.

Job satisfaction causes employees to be more enthusiastic to work so that they are more active in achieving the target. In addition, job satisfaction can also instill a strong commitment to employees. Likewise, vice versa, if employees feel not satisfied, there will be low commitment.

\section{Conclusions and Suggestions}

1. Conclusion

a. The quality of work life has a positive and positive effect significant to organizational commitment at PT. Intrasari Raya Bogor. This means that the quality of work life increases, the stronger organizational commitment.

b. Job satisfaction has a positive and significant effect on organizational commitment at PT. Intrasari Raya Bogor. This means that the more job satisfaction the employee increases, the more organizational commitment will be created.

c. The quality of work life and job satisfaction simultaneously (together) have a positive and significant effect on organizational commitment at PT. Intrasari Raya Bogor.

2. Suggestions for Companies

a. The company is expected to rethink in making other strategies related to the payroll system.

b. The company is also expected to maintain facilities and infrastructure a conducive work environment.

c. Companies can be more pay attention to promotion opportunities and career paths such as conducting employee training and development and giving awards to outstanding employees.

d. Companies leaders are also expected to be able to provide opportunities for employees so that they can show themselves by being given trust in their hard work.

\section{Further Research}

Expected to use even more aspects that can affect organizational commitment other than quality of work life and job satisfaction. For example aspects others who are able to create commitment are styles

leadership, work discipline, work design, role conflict, work stress, career development, organizational culture, and work motivation. So the results are obtained more complete and become a reference for success PT. Intrasari Raya Bogor.

\section{References}

Afifudin. (2017). Manajemen Sumber Daya Manusia. Bandung: CV. Pustaka Setia.

Apriansyah, G. (2014). Pengaruh Partisipasi Anggaran, Komimen Organisasi, Kepuasan Kerja, Job-Relevant Information dan Budaya Organisasi Terhadap Kinerja Manajerial pada Perhotelan di Provinsi Riau. JOM Fekon, 1 (2): 2-5.

Danik, D.A. (2015). Pengaruh Kualitas Kehidupan Kerja dan Kepuasan Kerja Terhadap Keterikatan Karyawan di PT. Telekomunikasi Indonesia. Universitas Atma Jaya

Sri Marti Pramudena and Asmy Fuzita Hilda. The effect of quality of worklife and job satisfaction on organizational commitment 
The Management Journal of BINANIAGA Vol. 04, No. 01, June 2019

p-ISSN: $2527-4317$, e-ISSN: $2580-149 x$

$6^{\text {th }}$ Accreditation Rating: April 04, 2019-April 03, 2024

Yogyakarta: Tesis.

Darmawan, D. (2013). Sistem Informasi Manajemen. Bandung: PT. Remaja Rosdakarya.

Hasibuan, M.S.P. (2008). Manajemen Dasar, Pengertian, dan Masalah. Jakarta: PT. Bumi Aksara.

Hayati, I.K. (2011). Analisis Penerapan Quality of Worklife (QWL) Terhadap Kepuasan Kerja dan Komitmen Organisasi. Institut Pertanian Bogor: Tesis.

Imanni, R.N., Andre, D.W. (2014). Pengaruh Kualitas Kehidupan Kerja Terhadap Komitmen Organisasi Melalui Motivasi Kerja. Jurnal IImu Manajemen. 2(3): 10921093.

Irawati, A. (2015). Pengaruh Kualitas Kehidupan Kerja Terhadap Kinerja Pegawai Dinas Perindustrian dan Perdagangan Kabupaten Sampang. Jurnal Neo-bis, 9(2): 41-51.

Jati, A.N. (2013). Kualitas Kehidupan Kerja dan Komitmen Organisasional: Hubungannya dan Organization Citizenship Behaviour. Jurnal Kiat Bisnis, 5(2): 86-90.

Kaswan. (2018). Perilaku Organisasi Positif. Bandung: CV. Pustaka Setia.

Melia, I., Anggraini, S. (2011). Analisis Komitmen Organisasi Melalui Faktor Quality of Worklife. Jurnal Manajemen dan Organisasi, 2(3): 80-88.

Oktavianti, I. (2014). Pengaruh Kepuasan Kerja dan Gaya Kepemimpinan Transformasional Terhadap Keinginan Keluar Karyawan dengan Komitmen Organisasi sebagai Variabel Mediasi. Journal of Economic Education, 3(2).

Priambodo, A. (2016). Pengaruh Kualitas Kehidupan Kerja Terhadap Komitmen Organisasi Melalui Motivasi Kerja Sebagai Variabel Intervening. Jurnal IImu Manajemen, 5(1): 6-9.

Puspitawati, N.M.D., Riana, I.G. (2014). Pengaruh Kepuasan Kerja dan Komitmen Organisasional dan Kualitas Pelayanan. Jurnal Manajemen Bisnis Kewirausahaan, 8 (1): 76-79.

Rahman, A. (2017). Kualitas Kehidupan Kerja: Suatu Tinjauan Literatur \& Pandangan dalam Konsep Islam. Jurnal IImiah Cano Ekonomos, 6(1): 7-19.

Robbins, S.P., Mary, C. (2016). Manajemen. Edisi Ketigabelas. Jakarta: Erlangga.

Robbins, S.P., Timothy, A.J. (2015). Perilaku Organisasi. Jakarta: Salemba Empat.

Rumengan, J. (2010). Metodogi Penelitian dengan SPSS. Batam: Uniba Press.

Santoso, S. (2012). Panduan Lengkap SPSS Versi 20. Jakarta: PT. Elex Media Komputindo.

Sijabat, J. (2011). Pengaruh Kepuasan Kerja Terhadap Komitmen Organisasi dan Keinginan untuk Pindah Tempat di KAP Surabaya. Visi, 19(3): 592-608.

Sugiyono. (2013). Metode Penelitian Kuantitatif, Kualitatif, dan R\&D. Bandung: Alfabeta. Bandung: Alfabeta.

(2016). Metode Penelitian Kuantitatif, Kualitatif, dan R\&D.

Sri Marti Pramudena and Asmy Fuzita Hilda. The effect of quality of worklife and job satisfaction on organizational commitment 
Sunyoto, D. (2012). Manajemen Sumber Daya Manusia. Jakarta: CAPS (Center of Academic Publishing Service).

Suparyadi. (2015). Manajemen Sumber Daya Manusia: Menciptakan Keunggulan Bersaing Berbasis Kompetensi SDM. Yogyakarta: CV. Andi Offset.

Sutrisno, E. (2010). Budaya Organisasi, Edisi Pertama. Jakarta: Kencana Prenada Media Group. Media Group.

(2015). Manajemen Sumber Daya Manusia. Jakarta: Kencana Prenada

Thoha, M. (2013). Perilaku Organisasi Konsep Dasar dan Implikasinya. Jakarta: PT. Raja Grafindo Persada.

Triatna, C. (2016). Perilaku Organisasi dalam Pendidikan. Bandung: PT. Remaja Rosdakarya.

Wirawan, (2015). Manajemen Sumber Daya Manusia Indonesia. Depok: PT. Rajagrafindo Persada.

Sri Marti Pramudena and Asmy Fuzita Hilda. The effect of quality of worklife and job satisfaction on organizational commitment 
The Management Journal of BINANIAGA Vol. 04, No. 01, June 2019 p-ISSN: 2527 - 4317, e-ISSN: $2580-149 x$

$6^{\text {th }}$ Accreditation Rating: April 04, 2019-April 03, 2024

This page intentionally be emptied.

Sri Marti Pramudena and Asmy Fuzita Hilda. The effect of quality of worklife and job satisfaction on organizational commitment 